\title{
Genetic merit for fertility traits in Holstein cows: III. Hepatic expression of somatotropic axis genes during pregnancy and lactation
}

\author{
S. B. Cummins, ${ }^{\star} †$ S. M. Waters, $\ddagger$ A. C. O. Evans, $†$ P. Lonergan, $†$ and S. T. Butler ${ }^{\star 1}$ \\ *Animal and Grassland Research and Innovation Centre, Teagasc, Moorepark, Fermoy, Co. Cork, Ireland \\ †School of Agriculture and Food Science, University College Dublin, Belfield, Dublin 4, Ireland \\ $\ddagger$ Animal and Grassland Research and Innovation Centre, Teagasc, Grange, Dunsany, Co. Meath, Ireland
}

\section{ABSTRACT}

The objective of this study was to characterize the circulating concentrations of insulin-like growth factor-I (IGF-I) and the hepatic expression of key genes regulating the somatotropic axis in cows divergent in genetic merit for fertility traits but with similar genetic merit for milk production traits. A total of 11 cows with good genetic merit for fertility (Fert+) and 12 cows with poor genetic merit for fertility (Fert-) underwent liver biopsy by percutaneous punch technique on d $20( \pm 6.7$ d) prepartum and on d $2( \pm 1.5 \mathrm{~d})$, d $58( \pm 3.7 \mathrm{~d})$, d $145( \pm 13 \mathrm{~d})$, and d 245 ( $\pm 17.1 \mathrm{~d})$ postpartum. Total RNA was isolated and the mRNA expression of growth hormone receptor (GHR $1 A$ and GHRtot), IGF-I, janus tyrosine kinase 2 (JAK2), signal transducer and activator of transcription 5B (STAT5B), suppressor of cytokine signaling 3 (SOCS-3), acid-labile subunit $(A L S)$, and IGF-binding proteins (IGFBP1 to IGFBP6) were measured by real-time quantitative PCR. During lactation, the circulating concentrations of IGF-I were $34 \%$ greater in Fert+ cows. The Fert+ cows had increased mean expression of IGF-I mRNA during the study; however, the difference in $I G F-I$ mRNA abundance between Fert+ and Fert- cows was most pronounced at d 145 and 245. The expression of IGFBP 3 and $A L S$ transcript was similar in Fert+ and Fert- cows for the duration of the study. The Fert- cows, however, had greater expression of $I G F B P 2, I G F B P 4, I G F B P 5$, and $I G F B P 6$. Genotype had no effect on mRNA abundance of GHR 1A, STAT5B, JAK2, or SOCS-3. Genetic merit for fertility traits affects hepatic expression of key genes of the somatotropic axis regulating the synthesis, bioavailability, and stability of circulating IGF-I.

Key words: genetic merit for fertility, somatotropic axis, insulin-like growth factor-I, fertility

Received September 26, 2011

Accepted February 10, 2012.

${ }^{1}$ Corresponding author: stephen.butler@teagasc.ie

\section{INTRODUCTION}

The modern dairy cow undergoes a coordinated series of physiological adaptations to support milk synthesis (Bauman, 2000). This is most noticeable during the early postpartum period, when the energy demand associated with increasing milk output is greater than the energy supplied by DMI. This energy deficit places the cow in a state of negative energy balance (NEB), resulting in mobilization of body reserves (Bauman and Currie, 1980). The growth hormone/insulin-like growth factor (somatotropic) axis plays a central role in the regulation of nutrient partitioning and key processes controlling reproductive efficiency. Therefore, it is seen as a potential biological mechanism linking nutritional status and reproduction (Lucy et al., 2001; Veerkamp et al., 2003). Perturbations in metabolic status, indicated by changes in circulating concentrations of IGF-I, have been demonstrated to be associated with reproductive efficiency (Wathes et al., 2003; Taylor et al., 2004; Patton et al., 2007).

Pituitary-derived growth hormone $(\mathbf{G H})$ stimulates hepatic IGF-I synthesis via a specific cell-surface GH receptor (GHR). The resulting systemic increase in IGF-I inhibits GH secretion, thereby completing the feedback loop and maintaining the system in equilibrium (Le Roith et al., 2001). Under conditions of NEB and BCS loss, the GH-IGF axis becomes uncoupled. The liver becomes refractory to GH during NEB, whereby elevated circulating concentrations of $\mathrm{GH}$ fail to stimulate an increase in hepatic IGF-I synthesis (Vicini et al., 1991; Lucy, 2008). The GH-IGF axis is regulated at multiple levels within the liver. The effect of GH on hepatic IGF-I synthesis is dependent on the abundance of cell-surface GHR and the availability and activity of intracellular signaling proteins responsible for activation (janus tyrosine kinase 2, JAK2; signal transducer and activator of transcription 5B, STAT5B) and regulation (suppressor of cytokine signaling 3 (SOCS-3; Jones and Clemmons, 1995; Ram and Waxman, 1999). Following hepatic IGF-I synthesis and release into circulation, plasma IGF-I concentrations are regulated by 
binding with 1 of the 6 IGF-binding proteins (IGFBP; 1 to 6 ) and the presence of IGFBP acid-labile subunit (ALS), altering the half-life and potential function of IGF-I (Le Roith et al., 2001).

Previous studies have developed high versus low fertility animal models through diet manipulation (Grala et al., 2011), comparing cows at different stages of lactation (Gross et al., 2011), comparing cows that became pregnant with cows that failed to become pregnant (Rhoads et al., 2008), or comparing cows of different genetic origin (New Zealand Holstein-Friesian vs. North American Holstein-Friesian; Lucy et al., 2009; McCarthy et al., 2009) to determine whether hepatic regulation of the GH-IGF axis is related to fertility. Although these studies provide valuable insight into the effects of energy status, lactation, and genetic origin on characteristics of the GH-IGF axis, they are confounded by effects of age, nutrition, stage of lactation, and BCS, among other factors.

Recently, we reported that genetic merit for fertility traits had a pronounced effect on reproductive efficiency, BCS profile, and circulating concentrations of IGF-I (Cummins et al., 2012). Cows with good (Fert+) genetic merit for fertility traits had greater circulating concentrations of IGF-I throughout lactation compared with cows with poor (Fert-) genetic merit for fertility traits. However, the underlying physiological differences between Fert+ and Fert- cows that regulate the observed differences in the circulating IGF-I concentration remain unknown. Therefore, the aim of this study was to determine the effect of genetic merit for fertility traits on transcriptional regulation of key genes controlling the hepatic GH-IGF axis during the gestation and lactation cycle.

\section{MATERIALS AND METHODS}

\section{Herd Establishment}

Animals with high and low genetic merit for fertility traits were assembled during autumn 2007 using official dairy evaluations published by the Irish Cattle Breeding Federation (Bandon, Co. Cork, Ireland), as outlined in detail by Cummins et al. (2012). In summary, the national dairy cattle database was screened for nulliparous spring-calving heifers that were of $>75 \%$ Holstein ancestry, and had an EBV for milk production between $+200 \mathrm{~kg}$ and $+900 \mathrm{~kg}$. Within this population, heifers with extreme negative (good fertility) and positive (poor fertility) EBV for calving interval were identified. A further restriction was placed on heifer sire and maternal grandsire EBV for calving interval. Good fertility (Fert+) heifers were restricted to animals where the sire and maternal grand sire had negative
EBV for calving interval. Conversely, poor fertility (Fert-) heifers were restricted to animals where sire and maternal grand-sire had positive EBV for calving interval. A total of 26 nulliparous Fert- and 26 nulliparous Fert+ cows were screened and found to be free of infectious diseases, and were purchased and moved to the Moorepark Animal and Grassland Research and Innovation Centre in Fermoy, Co. Cork, Ireland $\left(55^{\circ} 10^{\prime} \mathrm{N}\right.$ $\left.8^{\circ} 16^{\prime} \mathrm{W}\right)$. The total number of animals enrolled in the current study was 23 ; of these 11 were Fert+ (3 firstlactation and 8 second-lactation) and 12 were Fert- (4 first-lactation and 8 second-lactation). The subsample of animals selected for the current study calved between February 1 and May 5, and were representative of the larger groups of Fert+ and Fert- cows (e.g., range of sires, parity). The EBV of the 2 genotypes are summarized in Table 1.

\section{Management System}

For the duration of the study, animals were managed identically as one herd in a typical grass-based, spring-calving production system. Before parturition, cows were housed in a freestall barn and given full-time access to a TMR of grass silage (90\%) and concentrate $(10 \%)$. Following parturition, cows were turned out to grass in early February until mid November and grazed under a rotational grazing system in a predominantly perennial ryegrass (Lolium perenne L.) sward. The mean herbage allowance was $14.3 \pm 1.3 \mathrm{~kg} / \mathrm{d}$ of DM/ cow, supplemented with $4.0 \pm 1.7 \mathrm{~kg} /$ cow per day of concentrate. The chemical composition of the diet is summarized in Table 2. Cows were milked twice daily at 0730 and $1630 \mathrm{~h}$, and milk yield was recorded at each milking using electronic milk meters (Dairymaster, Causeway, Co. Kerry, Ireland). Milk composition (fat, protein, and lactose) was determined weekly from successive evening and morning samples by mid-infrared reflectance spectroscopy using a FT6000 Milkoscan instrument (Foss Electric, Hillerød, Denmark). Cow BW was measured weekly and BCS (Edmonson et al., 1989) was assessed every 2 to 3 wk throughout the study.

\section{Liver Tissue Sampling}

Liver tissue was collected from all cows on d $20( \pm 7 \mathrm{~d})$ prepartum and d $2( \pm 2 \mathrm{~d}), \mathrm{d} 58( \pm 4 \mathrm{~d}), \mathrm{d} 145( \pm 13 \mathrm{~d})$, and $\mathrm{d} 245( \pm 17 \mathrm{~d})$ postpartum. A percutaneous punch technique was used to collect liver tissue as described by Smith et al. (2003). In summary, a biopsy site on the right flank of the cow was shaved and sanitized with $7.5 \%$ iodinated povidone and methylated spirits. A subcutaneous injection of lidocaine hydrochloride $(2 \%)$ was used to anesthetize the area. A 1-cm incision 
Table 1. Mean $\mathrm{EBV}^{1}$ (SD) for cows with good genetic merit (Fert+) and those with poor genetic merit (Fert-) for fertility

\begin{tabular}{lcc}
\hline & \multicolumn{2}{c}{ Genotype } \\
\cline { 2 - 3 } Item & Fert+ & Fert- \\
\hline Animals (no.) & 11 & 12 \\
NAHF $\left.^{2} \%\right)$ & $92.6(5.92)$ & $94.1(6.05)$ \\
Milk (kg) & $+498.5(145.9)$ & $+469.2(118.9)$ \\
Fat (kg) & $+22.3(5.67)$ & $+18.7(7.39)$ \\
Protein (kg) & $+19.4(6.33)$ & $+18.8(7.31)$ \\
Fat (g/kg) & $+0.081(0.12)$ & $+0.023(0.125)$ \\
Protein (g/kg) & $+0.065(0.048)$ & $+0.065(0.062)$ \\
Survival (\%) & $+3.40(0.85)$ & $-0.04(1.09)$ \\
Calving interval (d) & $-6.34(1.80)$ & $+5.05(2.15)$ \\
Sire calving interval (d) & $-7.83(4.97)$ & $+7.14(2.57)$ \\
Maternal grandsire calving interval (d) & $-6.12(2.68)$ & $+5.60(2.97)$ \\
\hline${ }^{1}$ All PTA were obtained from the autumn 2007 official dairy evaluations published by the Irish Cattle Breeding \\
Federation and multiplied by 2 to convert to EBV. & & \\
${ }^{2}$ Percentage of North American Holstein-Friesian genes. & &
\end{tabular}

was made through the skin, and the biopsy instrument was used to pierce through the intercostal muscle and peritoneum. Once the liver was located, a 1- to $1.5-\mathrm{g}$ sample of liver tissue was removed. The sample was washed in sterile PBS, snap-frozen in liquid nitrogen, and stored at $-80^{\circ} \mathrm{C}$ until further analysis. The incision site was sutured and treated topically with $\mathrm{Du}$ phacycline aerosol (3.6\% oxytetracycline hydrochloride: Norbrook Laboratories Ltd., Newry, Northern Ireland).

\section{Blood Sampling and Laboratory Analysis}

Blood samples were collected to coincide with liver tissue collection time points. Blood samples were collected via coccygeal venipuncture into Vacutainers containing lithium heparin as an anticoagulant (Becton Dickinson, Plymouth, UK). Samples were centrifuged

Table 2. The mean (SD) chemical composition ( $\mathrm{g} / \mathrm{kg}$ of DM unless otherwise noted) of grass, grass silage, and concentrate

\begin{tabular}{lcc}
\hline & \multicolumn{2}{c}{ Feed } \\
\cline { 2 - 3 } Item & Forage & Concentrate \\
\hline Dry period $^{1}$ & $145.0(16.8)$ & $142.1(7.5)$ \\
CP & $504.0(26.6)$ & $234.5(7.5)$ \\
NDF & $361.4(31.6)$ & \\
ADF & $79.9(2.3)$ & $57.9(3.7)$ \\
Ash & & $86.3(6.07)$ \\
Crude fiber & $217.5(37.8)$ & $154.3(13.2)$ \\
Lactation ${ }^{2}$ & $424.0(40.6)$ & $270.0(32.0)$ \\
CP & $235.7(21.1)$ & $95.5(11.3)$ \\
NDF & $84.0(8.6)$ & \\
ADF & $805.9(39.9$ & $106.5(11.79)$ \\
$\quad$ Ash & & \\
OM digestibility (g/kg of OM) & & \\
Crude fiber & & \\
\hline${ }^{1}$ Forage consisted of grass silage. & & \\
${ }^{2}$ Forage consisted of grass. & &
\end{tabular}

for 15 min at 2,000 $\times g$, and plasma was decanted and stored at $-20^{\circ} \mathrm{C}$ until further analysis. Plasma insulin concentration was determined using a solid-phase fluoro-immunoassay (AutoDELFIA, PerkinElmer Life and Analytical Sciences, Turku, Finland), with appropriate kits (Unitech BD Ltd., Dublin, Ireland). Inter- and intraassay coefficients of variation were 17.5 and $8.5 \%$, respectively. Blood plasma was analyzed for circulating IGF-I concentrations, which were quantified using a validated double-antibody RIA, following an ethanol:acetone:acetic acid extraction step as described by Enright et al. (1989). Inter- and intraassay coefficients of variation were 15.6 and $15.8 \%$, respectively.

\section{RNA Extraction, cDNA Synthesis, and Real-Time Quantitative PCR}

Total RNA was isolated from $100 \mathrm{mg}$ of frozen liver tissue using TRI reagent (Sigma-Aldrich Ireland Ltd., Dublin, Ireland) and chloroform, and RNA was subsequently precipitated using isopropanol. The quantity and purity of RNA were determined by measuring absorbance at $260 \mathrm{~nm}$ on a spectrophotometer (NanoDrop Technologies, Wilmington, DE). All RNA samples had a 260:280 nm absorbance ratio between 1.94 and 2.14. The 28S:18S ratio and RNA integrity number, an indication of RNA quality, were assessed by automated capillary gel electrophoresis using an Agilent Bioanalyser with the RNA 6000 Nano LabChip kit (Agilent Technologies Ireland Ltd., Dublin, Ireland). The RNA samples had $28 \mathrm{~S}: 18 \mathrm{~S}$ ratios ranging from 1.5 to 2.3 and RNA integrity numbers between 7.5 and 9.3 and were deemed high quality and suitable for gene expression analysis. The samples were treated with RQ1 RNasefree DNase (Promega UK Ltd., Southampton, UK) and purified using an RNeasy Mini kit according to 
Table 3. Oligonucleotide primer sequence information used for real-time quantitative PCR assays

\begin{tabular}{|c|c|c|c|}
\hline Gene $^{1}$ & Primer sequence $\left(5^{\prime}\right.$ to $\left.3^{\prime}\right)$ & $\begin{array}{l}\text { Amplicon } \\
\text { size (bp) }\end{array}$ & Accession number \\
\hline RPS9 & $\begin{array}{l}\text { Forward: CCTCGACCAAGAGCTGAAG) } \\
\text { Reverse: CCTCCAGACCTCACGTTTGTTC }\end{array}$ & 64 & NM_001101152.1 \\
\hline JAK2 & $\begin{array}{l}\text { Forward: TTGGCAATGACAAACAAGGA } \\
\text { Reverse: ATCTCATCTGGGCATCCATC }\end{array}$ & 100 & XM_865133.2 \\
\hline CAP1 & $\begin{array}{l}\text { Forward: AGGCGGTGACTTCAATGAGTTCCC } \\
\text { Reverse: ACAAGGAACCCAGTGGCACTTCG }\end{array}$ & 121 & NM_001035010.1 \\
\hline SRRM2 & $\begin{array}{l}\text { Forward: CCAGCGCAACCTGTCCCTGG } \\
\text { Reverse: CCTCGTACCCCTGCTCCTCCA }\end{array}$ & 194 & XM_587832.5 \\
\hline PSMD2 & $\begin{array}{l}\text { Forward: CTGTGGCTGGGCTGCTCACC } \\
\text { Reverse: CCACATCCACTGCCTGGCCC }\end{array}$ & 183 & NM_001101197.1 \\
\hline ACTB & $\begin{array}{l}\text { Forward: ACTTGCGCAGAAAACGAGAT } \\
\text { Reverse: CACCTTCACCGTTCCAGTTT }\end{array}$ & 123 & ВТ030480 \\
\hline IGFBP2 & $\begin{array}{l}\text { Forward: CACATCCCCAACTGTGACAA } \\
\text { Reverse: GATCAGCTTCCCGGTGTTAG }\end{array}$ & 114 & NM_174555.1 \\
\hline IGFBP3 & $\begin{array}{l}\text { Forward: ACAGACACCCAGAACTTCTCCTC } \\
\text { Reverse: GTTCAGGAACTTGAGGTGGTTC }\end{array}$ & 101 & NM_174556.1 \\
\hline IGFBP4 & $\begin{array}{l}\text { Forward: ATGTGCCTGATGGAGAAAGG } \\
\text { Reverse: GCCATCCTGTGACTTCCTGT }\end{array}$ & 106 & NM_174557.3 \\
\hline IGFBP5 & $\begin{array}{l}\text { Forward: AAAGAAGCTGACCCAGTCCA } \\
\text { Reverse: CCCCTGCTCAGATTTCTGTC }\end{array}$ & 100 & NM_001105327.1 \\
\hline IGFBP6 & $\begin{array}{l}\text { Forward: GGAGAGAATCCCAAGGAGAGTA } \\
\text { Reverse: GAGTGGTAGAGGTCCCCGAGT }\end{array}$ & 100 & NM_001040495.1 \\
\hline ALS & $\begin{array}{l}\text { Forward: CTTCTGGCTGGACGTCTCC } \\
\text { Reverse: AAGGTCCTCAGCGAGTTGTTT }\end{array}$ & 111 & NM_001075963.1 \\
\hline GHRtot & $\begin{array}{l}\text { Forward: ATGGCGGTATTGTGGATCAT } \\
\text { Reverse: AGGATGTCGGCATGAATCTC }\end{array}$ & 121 & NM_176608.1 \\
\hline
\end{tabular}

${ }^{1}$ RPS9 = ribosomal protein S9; SOCS3 = suppressor of cytokine signaling 3; JAK2 = janus tyrosine kinase 2; STAT5B = signal transducer and activator of transcription 5B; CAP1 = adenylate cyclase-associated protein 1 ; SRRM2 = serine/arginine repetitive matrix 2 ; PSMD2 = 26S proteasome non-ATPase regulatory subunit $2 ; \mathrm{ACTB}=\beta$-actin; IGFBP1 = IGF binding protein-1; IGFBP2 = IGF binding protein-2; IGFBP3 = IGF binding protein-3; IGFBP4 = IGF binding protein-4; IGFBP5 = IGF binding protein-5; IGFBP6 = IGF binding protein-6; ALS = acidlabile subunit; GHRtot = growth hormone receptor; GHR 1A = growth hormone receptor 1A variant.

the manufacturer's instructions (Qiagen Inc., Valencia, CA).

One microgram of total RNA was reverse transcribed to cDNA, with random hexamers, using the High Capacity cDNA Reverse Transcription kit (Applied Biosystems, Warrington, UK), according to instructions supplied, and stored at $-20^{\circ} \mathrm{C}$.

Real-time quantitative PCR (RT-qPCR) was used to measure expression of genes involved in the somatotropic axis, their transcriptional regulators, and reference genes. Primers were designed to specifically amplify templates of between 64 and 194 nucleotides overlapping exon-exon junctions where possible, using Primer-Blast software (http://www.ncbi.nlm.nih.gov/ tools/primer-blast/index.cgi). The sequences of primers used for each gene were commercially synthesized (Sigma-Aldrich Ireland Ltd.) and are summarized in
Table 3. The PCR products generated by amplification were sequenced to verify their identity and confirm primer specificity (Eurofins MWG Operon, Ebersberg, Germany).

The stability of expression of candidate reference genes was investigated across all samples in the study. Reference genes included $\beta$-actin $(A C T B)$, ribosomal protein S9 (RPS9), adenylate cyclase-associated protein 1 (CAP1), serine/arginine repetitive matrix 2 (SRRM2), and 26S proteasome non-ATPase regulatory subunit 2 (PSMD2). The resulting expression data were analyzed using geNorm software (version 3.5, Excel add-in, Microsoft, Redmond, WA) as described by Vandesompele et al. (2002) to test the overall stability of the tested reference genes. The program estimates an expression stability value $(\boldsymbol{M})$ for each reference gene (the lowest $M$ value being the most stable). By 
performing a stepwise exclusion of reference genes with the highest $M$ values, geNorm determines the minimal number of reference genes required for calculating an accurate normalization factor. In the current study, the highest stability was achieved by including 3 reference genes, PDSM2, CAP1, and ACTB, achieving a combined $M$ value of 0.29 .

All RT-qPCR reactions were performed using SYBR Fast Green mastermix (Applied Biosystems). Assays were carried out under identical conditions, and all samples were measured in triplicate using the Applied Biosystems Fast 7500 v2.0.1 instrument with the following cycle parameters $\left(95^{\circ} \mathrm{C}\right.$ for $15 \mathrm{~s}, 60^{\circ} \mathrm{C}$ for $60 \mathrm{~s}, 95^{\circ} \mathrm{C}$ for $15 \mathrm{~s}$, and $60^{\circ} \mathrm{C}$ for $\left.15 \mathrm{~s}\right)$. Primer and cDNA concentrations were optimized for each gene. The efficiency of the reaction was calculated using a 5 -fold dilution series of cDNA to generate a standard curve. Dissociation curves were examined for the presence of a single PCR product. All PCR efficiency coefficients were between 0.9 and 1.08 and therefore deemed acceptable. The software package GenEx 5.2.1.3 (MultiD Analyses AB, Gothenburg, Sweden) was used for efficiency correction of the raw cycle threshold values, interplate calibration based on a calibrator sample included on all plates, averaging of replicates, normalization to the reference gene, and the calculation of quantities relative to the highest cycle threshold value.

\section{Statistical Analysis}

All statistical analyses and data handling were carried out using SAS software (SAS Institute Inc., Cary, NC). Data were checked for normality and homogeneity of variance. Plasma hormone concentrations (IGF-I and insulin) and all gene expression data underwent transformation by raising the variable to the power of lambda. A Box-Cox transformation analysis was used to obtain the appropriate lambda value and normalize the distribution.

The effect of genotype on variables with repeated measures such as milk yield, BCS, BW, plasma hormone concentrations of insulin and IGF-I, and gene expression data were determined using mixed models with cow nested within genotype as a random effect. A first-order autoregressive covariance structure with homogeneous variance provided the best fit for the data. Transformed data were used to calculate $P$-values, and the estimated group means and $95 \%$ confidence intervals reported are back-transformed values. The effects of genotype, time, parity, and their interactions were tested. Calving date was included as an adjustment variable, and significant effects $(P<0.1)$ were maintained in the final model. Preplanned contrasts using the ESTIMATE statement were carried out to compare gene expression data between Fert+ and Fert- cows during 3 distinct time periods: the dry period ( $\mathrm{wk}-3$ ), early lactation (wk 1 and wk 8), and mid to late lactation (wk 20 and wk 35).

\section{RESULTS}

\section{Production Variables and Plasma Hormone Concentrations}

The effect of genotype on milk production, BCS, and circulating concentrations of insulin and IGF-I are illustrated in Figure 1. Genotype had no effect $(P=0.9)$ on mean daily milk yield, but the genotype by time interaction was significant. Parity had a significant effect on milk yield $(17.6 \pm 1.5 \mathrm{~kg} / \mathrm{d}$ vs. $21.6 \pm 1.0$ $\mathrm{kg} / \mathrm{d}$ for parity 1 and parity 2 , respectively). Trends in BCS were similar $(P=0.4)$ for both genotypes during the 5 sample periods. The lowest mean BCS was recorded during the third sample period (wk 8), with only modest increases observed thereafter until the end of lactation. Genotype had no effect $(P=0.8)$ on the mean BW of Fert+ and Fert- cows over the duration of the study (521 $\pm 16 \mathrm{~kg}$ and $527 \pm 15$, respectively). No difference was observed in prepartum circulating IGF-I concentrations. During lactation, however, the circulating concentrations of IGF-I were $34 \%$ greater in Fert + cows than in Fert- cows. Genotype had no effect on plasma insulin concentrations during wk $-3,8,20$, or 35 (relative to parturition); however, Fert+ cows had $89 \%$ greater plasma insulin concentration during the first week of lactation compared with Fert- cows $(P$ $<0.05)$.

\section{Gene Expression Profiles for Duration of the Study}

The effect of genotype on gene expression data are presented in Figures 2, 3, and 4. Genotype affected $I G F-I$ transcript abundance during the study: Fert+ cows had greater $(P<0.05)$ gene expression of $I G F$ $I$ (Figure 2A). No differences $(P=0.9)$ in $G H R 1 A$ transcript abundance was observed between genotypes (Figure 2B), but Fert- cows had greater GHRtot transcript abundance $(P<0.05)$. No differences $(P>$ $0.05)$ were observed in mean transcript abundance of IGFBP 1 and IGFBP 3 between Fert+ and Fert- cows (Figure $3 \mathrm{~A}$ and $3 \mathrm{C}$ ). The Fert- cows had greater $(P<0.05)$ mRNA abundance of IGFBP2, IGFBP 4 , $I G F B P 5$, and IGFBP6 over the duration of the study (Figure 3B, 3D, 3E, 3F). The majority of the lowmolecular-mass IGFBP expression differences between Fert + and Fert - cows can be accounted for during wk $-3,1$, and 8 relative to parturition. No differences $(P$ $>0.05)$ between genotypes were observed for transcript 

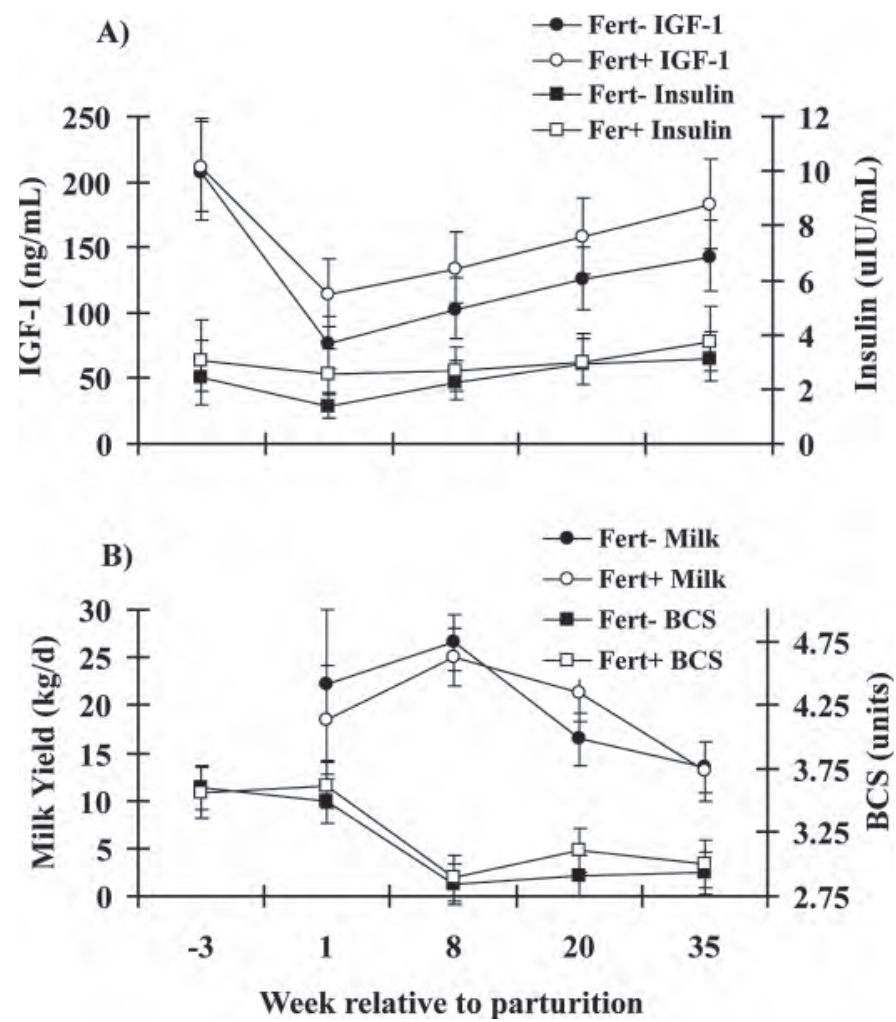

Figure 1. Circulating concentrations of IGF-I and insulin and mean daily milk yield and BCS during the gestation/lactation cycle in cows with good genetic merit (Fert+) and those with poor genetic merit (Fert-) for fertility. Vertical bars indicate 95\% CI. (A) Plasma IGF-I concentrations were significantly greater in Fert+ cows $(P<$ $0.001)$ during lactation. The mean $(95 \% \mathrm{CI})$ circulating IGF-I concentrations were $146.6 \mathrm{ng} / \mathrm{mL}(126.0,168.8)$ and $110.0 \mathrm{ng} / \mathrm{mL}(93.7$, 127.1) for Fert+ and Fert- cows, respectively. No effect of genotype was observed for plasma insulin concentrations $(P=0.1)$. The mean (95\% CI) circulating insulin concentrations were $2.96 \mathrm{uIU} / \mathrm{mL}(2.41$, $3.62)$ and $2.34 \mathrm{uIU} / \mathrm{mL}(1.90,2.85)$ for Fert+ and Fert-, respectively. No genotype $\times$ week or genotype $\times$ parity interactions were observed for IGF-I or insulin. (B) No effect of genotype or genotype $\times$ parity interaction was observed for daily milk yield $(P>0.05)$. There tended to be a significant genotype $\times$ week interaction $(P<0.05)$ for daily milk yield during the study period. No genotype $(P=0.4)$, genotype $\times$ week $(P=0.3)$, or genotype $\times$ parity $(P=0.8)$ effects were detected for $\mathrm{BCS}$ (SED $=0.09$ units).

abundance of JAK2, STAT5B, SOCS-3, or ALS during any of the 5 time points examined in this study (Figure 4).

\section{Genotype Contrasts of Gene Expression During the Dry Period, Early Lactation, and Mid to Late Lactation}

Genotype had no effect on $I G F-I$ mRNA abundance during the dry period or early lactation $(P>0.05)$; however, Fert+ cows exhibited greater $(P<0.01)$ abundance of $I G F-I$ mRNA during mid to late lactation compared with Fert- cows. Genotype had no effect on
Fert- $\square$ Fert+
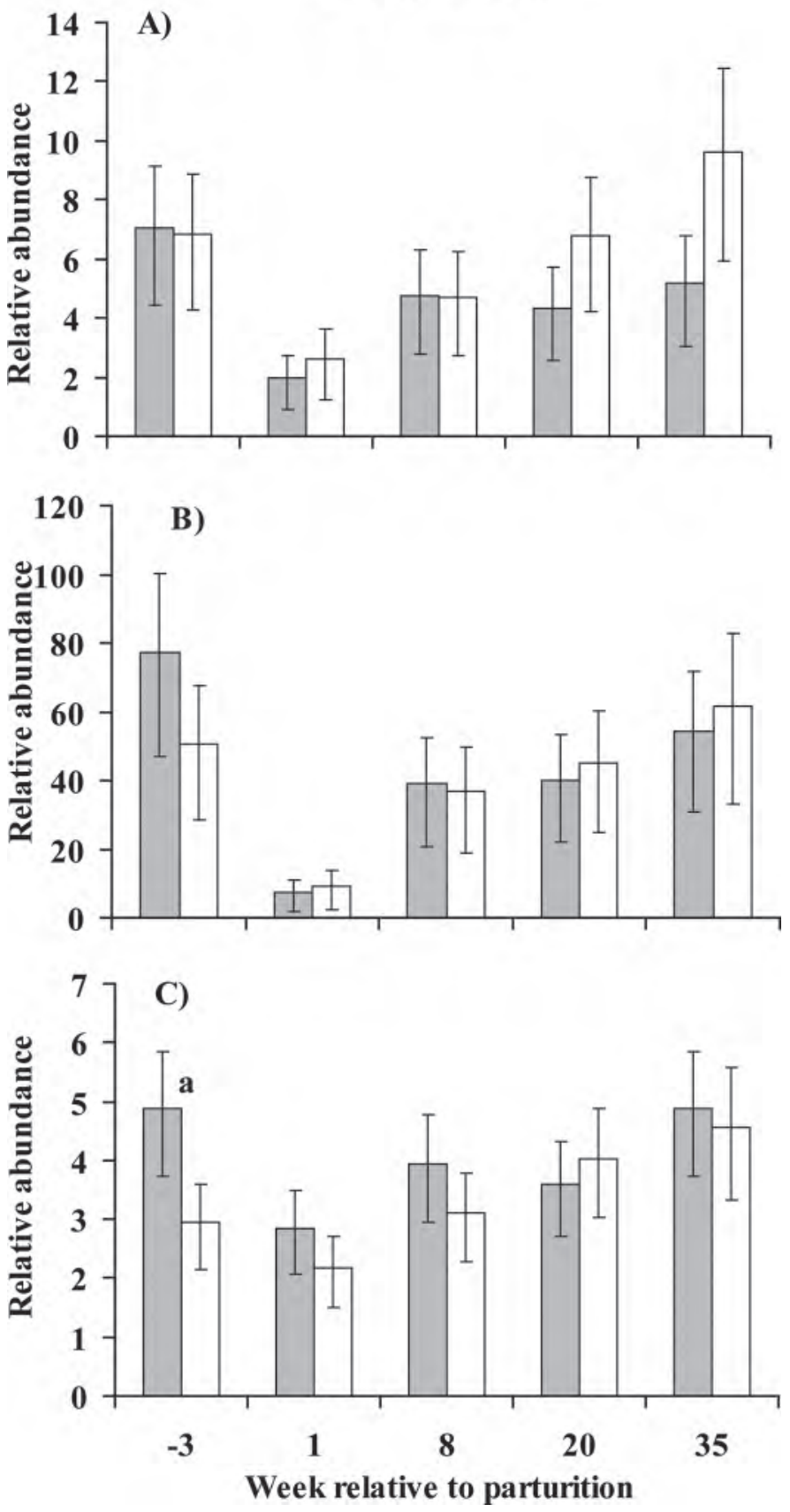

Figure 2. Relative abundance of mRNA in liver for (A) IGF-I, (B) growth hormone receptor $1 \mathrm{~A}$ variant (GHR 1A), and (C) growth hormone receptor (GHRtot) during wk $-3,1,8,20$, and 35 relative to parturition in cows with good genetic merit (Fert+) and those with poor genetic merit (Fert-) for fertility. Vertical bars indicate $95 \%$ CI. (A) IGF-I: IGF-I mRNA abundance was significantly greater in Fert+ cows $(P<0.05)$ over the duration of the study. No genotype $\times$ week or genotype $\times$ parity interaction existed $(P>0.05)$; (B) GHR 1A: no genotype, genotype $\times$ week, or genotype $\times$ parity interaction effects were detected for transcript abundance of GHR 1A $(P>0.05) ;(\mathrm{C})$ GHRtot: transcription of GHRtot was significantly greater in Fertcows $(P<0.05)$ over the duration of the study; a denotes differences at $P<0.1$. 
$\square$ Fert- $\square$ Fert+
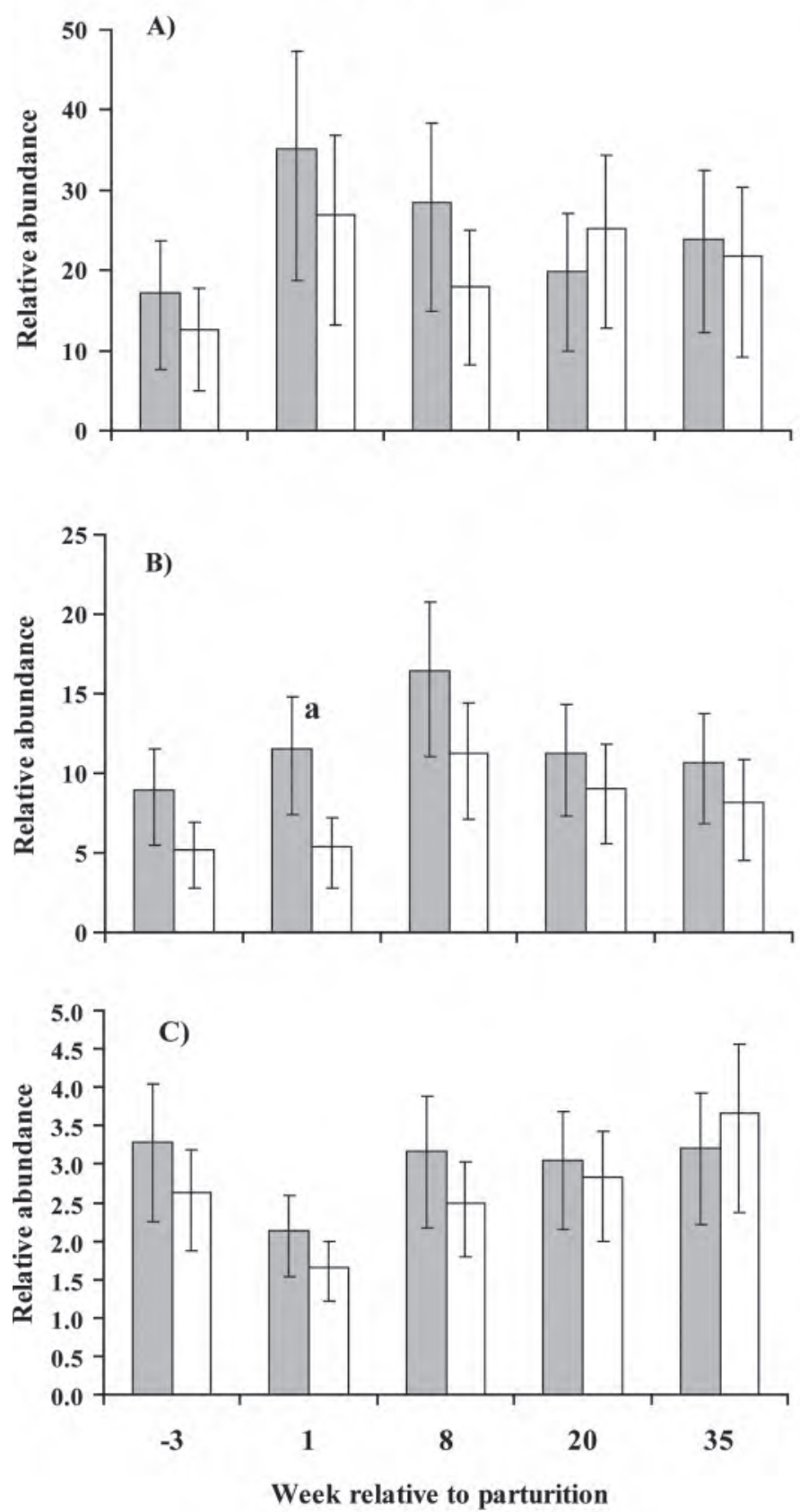
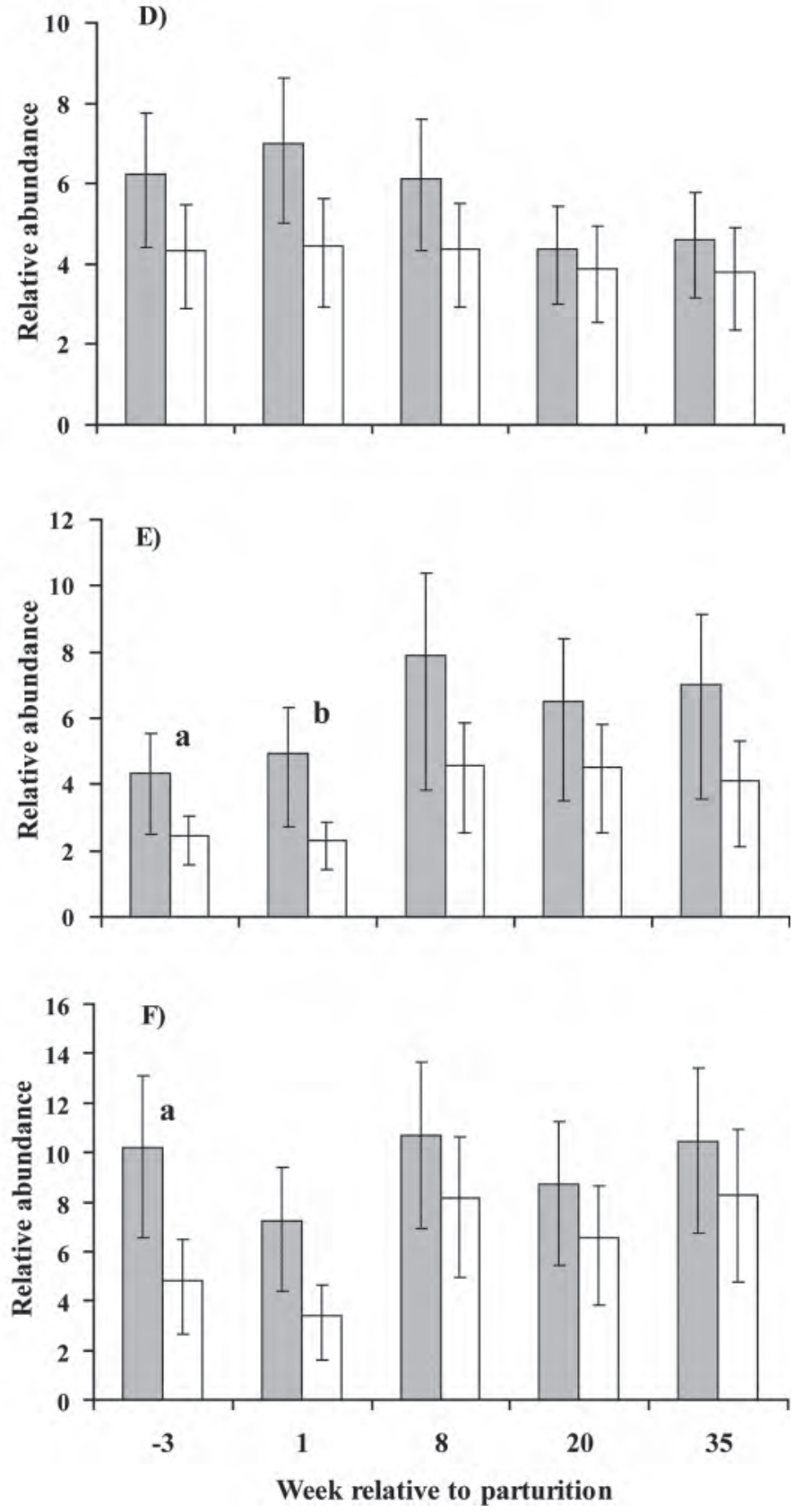

Figure 3. Relative abundance of mRNA in liver for (A) IGF-binding protein (IGFBP)1, (B) IGFBP2, (C) IGFBP3, (D) IGFBP4, (E) IGFBP5, and (F) IGFBP6 during wk $-3,1,8,20$, and 35 relative to parturition in cows with good genetic merit (Fert+) and those with poor genetic merit (Fert-) for fertility. Vertical bars indicate 95\% CI. (A) No effect of genotype was detected for transcript abundance of IGFBP1 $(P=0.3)$; (B) IGFBP2 mRNA abundance was significantly greater in Fert- cows $(P=0.003)$ over the duration of the study; $(\mathrm{C})$ no effect of genotype was detected for mean transcript abundance of IGFBP3 during the 5 sample time points $(P=0.17)$; $(\mathrm{D})$ IGFBP4 mRNA abundance was significantly greater in Fert- cows $(P=0.027)$ over the duration of the study; (E) Fert- cows had significantly greater IGFBP5 mRNA than Fert + cows throughout the study period $(P<0.001) ;(\mathrm{F})$ abundance of IGFBP6 mRNA was significantly greater in Fert - cows $(P=0.013)$ over the duration of the study. No genotype $\times$ week or genotype $\times$ parity interactions existed for any of the 6 IGFBP $(P>0.05)$; a denotes differences at $P<0.1$, and $\mathrm{b}$ denotes differences at $P<0.05$.

transcript abundance of $G H R 1 A$ during any of the 3 time periods $(P>0.05)$. The Fert- cows had greater expression of GHRtot mRNA during the dry period ( $P$
$<0.01)$ and early lactation $(P<0.05)$ compared with Fert + cows, but no differences between genotypes were observed in mid to late lactation $(P>0.05)$. Expression 

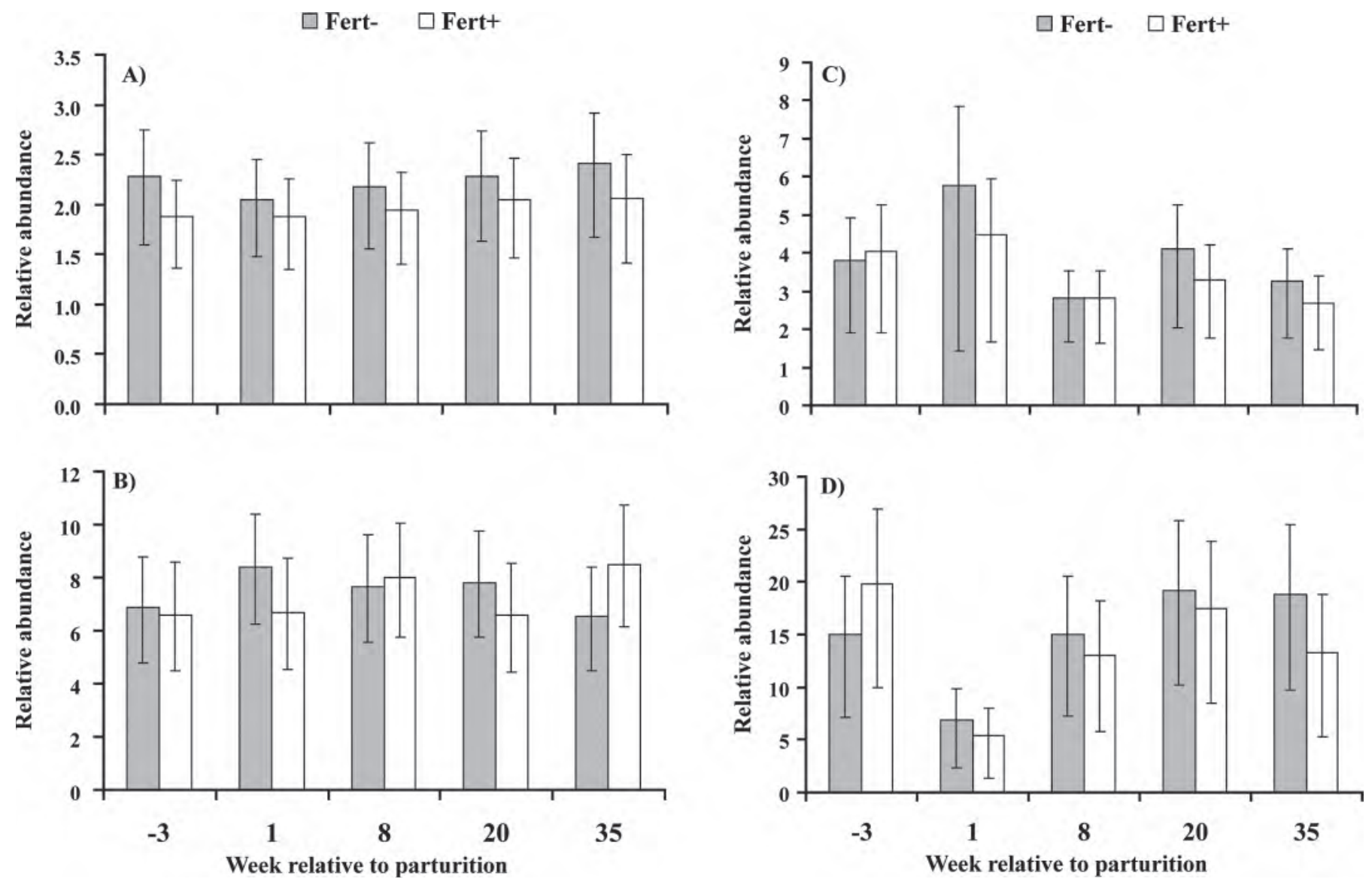

Figure 4. Relative abundance of mRNA in liver for (A) janus tyrosine kinase 2 (JAK2), (B) signal transducer and activator of transcription 5B (STAT5B), (C) suppressor of cytokine signaling 3 (SOCS-3), and (D) acid-labile subunit (ALS) during wk $-3,1,8,20$, and 35 relative to parturition in cows with good genetic merit (Fert+) and those with poor genetic merit (Fert-) for fertility. Vertical bars indicate $95 \%$ confidence intervals. Genotype, genotype $\times$ week, or genotype $\times$ parity interactions had no effect on mRNA abundance of JAK2 $(P=0.3)$, STAT5B $(P=$ $0.9)$, SOCS-3 $(P=0.5)$, or ALS $(P=0.7)$.

of IGFBP1 and IGFBP3 mRNA were similar for both genotypes during the dry period, early lactation, and mid to late lactation $(P>0.05)$. The Fert - cows had a greater $(P<0.05)$ abundance of IGFBP2 and IGFBP6 mRNA during the dry period and early lactation, but no difference was observed between genotypes during mid to late lactation. The Fert- cows had greater $(P$ $<0.05)$ mRNA abundance of IGFBP 4 during early lactation, but no differences between genotypes were observed during the dry period or mid to late lactation $(P>0.05)$. Expression of IGFBP5 mRNA was significantly greater $(P<0.01)$ in Fert- cows at all 3 time points compared with that in Fert+ cows.

\section{DISCUSSION}

This study compared the mRNA abundance of key genes in the somatotropic axis in cows with extremes in genetic merit for fertility traits during the gestationlactation cycle. Factors known to alter the somatotropic axis such as plane of nutrition, BW, age, stage of lactation, genetic merit for milk production, and proportion of Holstein genetics were similar for both genotypes. The current study attempted to elucidate the orchestrated physiological changes occurring in liver tissue that could explain the previously reported differences in circulating IGF-I and reproductive performance between Fert+ and Fert- cows (Cummins et al., 2012). The Fert+ cows had greater circulating concentrations of IGF-I throughout lactation, greater $I G F-I$ gene expression during mid to late lactation, and lower abundance of mRNA encoding lower-molecularmass binding proteins during early lactation compared with Fert- cows. The present study indicated that genetic merit for fertility traits alters components of the somatotropic axis regulating synthesis, bioavailability, and stability of circulating IGF-I. 
Uncoupling of the somatotropic axis is a common phenomenon in high-yielding dairy cows during the early postpartum period (Lucy, 2008). In the current study, plasma IGF-I concentrations declined in both genotypes following parturition, but the magnitude of decline was greater in the Fert- cows. The Fert+ cows maintained a $34 \%$ greater concentration of plasma IGF-I throughout lactation compared with Fert- cows, in agreement with the large body of evidence linking peripheral IGF-I to reproductive parameters (Lucy et al., 1998; Patton et al., 2007; Wathes et al., 2007). Given that nutrition, DMI, energy balance, and milk production were similar in both genotypes (Cummins et al., 2012), the observed differences in circulating IGF-I appear to be dependent on genetic merit for fertility traits.

The actions of GH on hepatocytes to synthesize IGF-I are transduced by cell-surface GHR (Lucy et al., 2001). The 3 most prevalent transcript variants for bovine GHR protein are GHR $1 A, 1 B$, and $1 C$ (Jiang and Lucy, 2001). The abundance of GHR $1 A$ mRNA has been shown to be influenced by plane of nutrition and DMI, and the decline in GHR $1 A$ expression is thought to be a primary factor causing hepatic refractoriness to GH-dependent IGF-I synthesis during the early postpartum period (Lucy et al., 2001). In the current study, the profile of GHR $1 A$ expression was similar to that in previous reports (Kobayashi et al., 1999), with a nadir shortly after parturition followed by an increase and plateau during mid lactation. No difference was observed between genotypes in GHR $1 \mathrm{~A}$ mRNA abundance. Moreover, Fert- cows exhibited lesser circulating concentrations of IGF-I but greater abundance of total GHR mRNA, particularly in early lactation. Previous reports have highlighted the strong association between circulating IGF-I concentrations and abundance of GHR in cows with different degrees of NEB (Fenwick et al., 2008a). In the current study, however, energy balance was similar between genotypes (Cummins et al., 2012), indicating that the observed differences in peripheral IGF-I concentration in Fert+ was dependent on factors other than GHR mRNA abundance. This is consistent with results reported by McCarthy et al. (2009), who compared hepatic gene expression in Holstein-Friesian cows of New Zealand and North American ancestry that exhibited similar postpartum energy balance.

The binding of GH to the GHR initiates a signaling cascade by activating the JAK-STAT intracellular pathway. The JAK2 protein causes phosphorylation of a DNA binding protein (STAT5B), which stimulates the transcription of GH-dependent genes such as IGF$I$ (Carter-Su et al., 2000; Horvath, 2000). A negative feedback mechanism to downregulate GH signaling is provided by SOCS3 (Ram and Waxman, 1999). In the current study, genotype had no effect on JAK2, STAT5B, or SOCS3 mRNA abundance in liver tissue. Levels of JAK2 and STAT5B appeared to be unaltered by physiological state and remained relatively stable throughout the gestation and lactation cycle, with mRNA abundance of SOCS3 increasing only during the early postpartum period. The absence of changes in the mRNA abundance of JAK-STAT pathway genes in different physiological states agrees with the results from short-term feed restriction, where cows were fed $30 \%$ of maintenance requirements for 2 wk (Rhoads et al., 2007). Although gene knockout studies in mice identified STAT5B as a key agent regulating GH-dependent IGF-I gene expression in the liver (Teglund et al., 1998; Woelfle and Rotwein, 2004), the current study demonstrated that peripheral concentrations of IGFI were not dependent on changes in STAT5B mRNA expression. Downstream regulation of the JAK-STAT pathway by SOCS3 protein could, however, partially explain the early postpartum decline in circulating IGF-I concentration. Based on these findings, greater circulating concentrations of IGF-I observed in Fert+ cows did not occur as a result of alterations in the intracellular signaling pathways that were measured.

Following the successful translocation of the dimerized STAT5B protein to the nucleus, transcription of IGF-I mRNA can occur (Horvath, 2000). As the liver is the primary source of circulating IGF-I, a strong association exists between hepatic $I G F-I$ mRNA and circulating concentrations of IGF-I (Sjögren et al., 1999; Radcliff et al., 2003). In the current study, Fert+ cows had greater transcription of $I G F-I$ mRNA in mid and late lactation, which coincided with greater circulating IGF-I. During the early postpartum period, however, greater circulating concentrations of IGF-I in Fert+ cows were not due to greater $I G F-I$ mRNA abundance. A similar lack of association was reported in a study comparing hepatic gene expression in Holstein-Friesian cows of New Zealand and North American ancestry during the early postpartum period (Grala et al., 2011). The authors suggested that posttranslation mechanisms altered IGF-I protein synthesis during the early postpartum period. A similar possibility cannot be ruled out in the present study, and furthered investigation is warranted.

Once released from the cell, the majority (95-99\%) of IGF ligands in circulation are bound to 1 of 6 potential binding proteins (IGFBP1 to 6), and the specific IGFBP that binds with IGF plays a critical role in the somatotropic axis by regulating physiological activity of IGF (Rajaram et al., 1997; Le Roith et al., 2001; Renaville et al., 2002). Produced almost entirely in the liver, the IGFBP act as carrier proteins transporting 
IGF out of circulation to target tissues and extend the half-life of IGF by preventing rapid metabolic clearance. Once in circulation, nonbound (free) IGF-I has a half-life of less than 10 min. Half-life is increased to 30 to $90 \mathrm{~min}$ if IGF-I is bound to lower-molecular-mass binding proteins (IGFBP1, 2, 4, 5, and 6), and further increased to 12 to $15 \mathrm{~h}$ if bound to the larger-molecularmass binding protein (IGFBP3) in a ternary complex with ALS (Guler et al., 1989; Jones and Clemmons, 1995). In addition, IGF-I has been shown to have a greater affinity to its binding proteins than to its receptor, creating a further mechanism altering bioavailability of IGF to target cells (Duan, 2002). In the current study, mRNA abundance of all IGFBP was affected by stage of the gestation-lactation cycle. Transcription of the more stable IGFBP3 and ALS declined during early lactation, whereas mRNA abundance of the lower-molecular-mass binding proteins (IGFBP1, 2, and 4) increased. The greater abundance of IGFBP2 mRNA during early lactation observed in Fert- cows was consistent with the inhibitory role of IGFBP2 on circulating IGF-I (Fenwick et al., 2008b; McCarthy et al., 2009; Gross et al., 2011).

A notable feature of the current study was the difference between genotypes in the abundance of lowmolecular-mass binding protein mRNA $(I G F B P 2,4,5$, and 6 ). For the duration of the study, Fert+ cows had similar abundance of IGFBP3 and $A L S$ mRNA, but had lesser abundance of mRNA encoding IGFBP2, 4, 5, and 6 compared with Fert- cows. The marked increase in the mRNA abundance of low-molecular-mass binding proteins during early lactation in Fert- cows could have arisen as a result of reduced circulating concentrations of insulin. Elevated circulating insulin concentrations during early lactation cause a rapid reduction in plasma concentrations of IGFBP-2 and other lowmolecular-mass binding proteins (Butler et al., 2003, 2004). Elevated insulin concentrations (4- to 8-fold increase) during early lactation have been demonstrated to increase GHR $1 A$ and IGF-I gene expression (Butler et al., 2003; Rhoads et al., 2004). The more modest difference between genotypes in circulating insulin concentrations during early lactation in the current study was not associated with concomitant differences in hepatic GHR $1 A$ or IGF-I transcript abundance. Collectively, the results indicate that expression of low-molecularmass IGFBP is more sensitive to changes in circulating insulin concentrations than GHR $1 A$ or IGF-I. We hypothesize that the Fert- cows had an increased proportion of IGF-I bound to low-molecular-mass binding proteins in early lactation compared with Fert+ cows. Because of the shorter half-life of IGF-I bound to lowmolecular-mass binding proteins, circulating IGF-I was reduced in Fert- cows in early lactation. In mid to late lactation, differences between genotypes in the mRNA abundance of the low-molecular-mass binding proteins were not as pronounced but IGF-I gene expression was greater in Fert+ cows during this time compared with Fert- cows.

\section{CONCLUSIONS}

The current study demonstrates the effects that genetic merit for fertility traits have on the regulation of the somatotropic axis in liver throughout the gestation-lactation cycle in Holstein cows. The elevated circulating concentrations of IGF-I observed in Fert+ cows could be explained in part by the reduction in expression of lower-molecular-mass binding protein mRNA during the early postpartum period, resulting in a greater proportion of circulating IGF-I bound to the more stable ternary complex. Moreover, greater peripheral IGF-I concentrations in Fert+ cows is attributed to greater abundance of $I G F-I$ mRNA during mid and late lactation, and appeared to be independent of abundance of hepatic mRNA for GHR or alterations in the JAK-STAT intracellular pathway. The current study indicates that the mechanisms responsible for increased IGF-I in cows with superior genetic merit for fertility traits differ depending on the stage of lactation.

\section{ACKNOWLEDGMENTS}

The authors thank J. P. Murphy and the Moorepark farm staff (Fermoy, Co. Cork, Ireland) for management and care of the animals. We also thank M. McCabe (Animal and Bioscience Department, Teagasc Grange, Dunsany, Co. Meath, Ireland) for his technical assistance. National Development Plan and Dairy Levy funding is gratefully acknowledged.

\section{REFERENCES}

Bauman, D. E. 2000. Regulation of nutrient partitioning during lactation: Homeostasis and homeorhesis revisited. Pages 311-327 in Ruminant Physiology: Digestion, Metabolism and Growth and Reproduction. CABI Publishing, New York, NY.

Bauman, D. E., and W. B. Currie. 1980. Partitioning of nutrients during pregnancy and lactation: A review of mechanisms involving homeostasis and homeorhesis. J. Dairy Sci. 63:1514-1529.

Butler, S. T., A. L. Marr, S. H. Pelton, R. P. Radcliff, M. C. Lucy, and W. R. Butler. 2003. Insulin restores GH responsiveness during lactation-induced negative energy balance in dairy cattle: Effects on expression of IGF-I and GH receptor 1A. J. Endocrinol. 176:205-217.

Butler, S. T., S. H. Pelton, and W. R. Butler. 2004. Insulin increases $17 \beta$-estradiol production by the dominant follicle of the first postpartum follicle wave in dairy cows. Reproduction 127:537-545.

Carter-Su, C., L. Rui, and J. Herrington. 2000. Role of the tyrosine kinase JAK2 in signal transduction by growth hormone. Pediatr. Nephrol. 14:550-557.

Cummins, S. B., P. Lonergan, A. C. O. Evans, D. P. Berry, R. D. Evans, and S. T. Butler. 2012. Genetic merit for fertility traits 
in Holstein cows: I. Production characteristics and reproductive efficiency in a pasture-based system. J. Dairy Sci. 95:1310-1322.

Duan, C. 2002. Specifying the cellular responses to IGF signals: Roles of IGF-binding proteins. J. Endocrinol. 175:41-54.

Edmonson, A. J., I. J. Lean, L. D. Weaver, T. Farver, and G. Webster. 1989. A body condition scoring chart for Holstein dairy cows. J. Dairy Sci. 72:68-78.

Enright, W. J., L. T. Chapin, W. M. Moseley, S. A. Zinn, M. B. Kamdar, L. F. Krabill, and H. A. Tucker. 1989. Effects of infusions of various doses of bovine growth hormone-releasing factor on blood hormones and metabolites in lactating Holstein cows. J. Endocrinol. 122:671-679.

Fenwick, M. A., R. Fitzpatrick, A. Kenny David, M. G. Diskin, J. Patton, J. Murphy, and D. C. Wathes. 2008a. Interrelationships between negative energy balance (NEB) and IGF regulation in liver of lactating dairy cows. Domest. Anim. Endocrinol. 34:31-44.

Fenwick, M. A., S. Llewellyn, R. Fitzpatrick, D. A. Kenny, J. J. Murphy, J. Patton, and D. C. Wathes. 2008b. Negative energy balance in dairy cows is associated with specific changes in IGF-binding protein expression in the oviduct. Reproduction 135:63-75.

Grala, T. M., M. C. Lucy, C. V. C. Phyn, A. J. Sheahan, J. M. Lee, and J. R. Roche. 2011. Somatotropic axis and concentrate supplementation in grazing dairy cows of genetically diverse origin. J. Dairy Sci. 94:303-315.

Gross, J., H. A. van Dorland, F. J. Schwarz, and R. M. Bruckmaier. 2011. Endocrine changes and liver mRNA abundance of somatotropic axis and insulin system constituents during negative energy balance at different stages of lactation in dairy cows. J. Dairy Sci. 94:3484-3494.

Guler, H.-P., J. Zapf, C. Schmid, and E. R. Froesch. 1989. Insulin-like growth factors I and II in healthy man. Acta Endocrinol. (Copenh.) 121:753-758.

Horvath, C. M. 2000. STAT proteins and transcriptional responses to extracellular signals. Trends Biochem. Sci. 25:496-502.

Jiang, H., and M. C. Lucy. 2001. Variants of the 5'-untranslated region of the bovine growth hormone receptor mRNA: Isolation, expression and effects on translational efficiency. Gene 265:45-53.

Jones, J. I., and D. R. Clemmons. 1995. Insulin-like growth factors and their binding proteins: Biological actions. Endocr. Rev. 16:3-34.

Kobayashi, Y., C. K. Boyd, C. J. Bracken, W. R. Lamberson, D. H. Keisler, and M. C. Lucy. 1999. Reduced growth hormone receptor (GHR) messenger ribonucleic acid in liver of periparturient cattle is caused by a specific down regulation of GHR 1A that is associated with decreased insulin-like growth factor I. Endocrinology 140:3947-3954.

Le Roith, D., C. Bondy, S. Yakar, J.-L. Liu, and A. Butler. 2001. The somatomedin hypothesis: 2001. Endocr. Rev. 22:53-74.

Lucy, M. C. 2008. Functional differences in the growth hormone and insulin-like growth factor axis in cattle and pigs: Implications for post-partum nutrition and reproduction. Reprod. Domest. Anim. 43:31-39.

Lucy, M. C., H. Jiang, and Y. Kobayashi. 2001. Changes in the somatotropic axis associated with the initiation of lactation. J. Dairy Sci. 84(E-Suppl. ):E113-E119.

Lucy, M. C., G. A. Verkerk, B. E. Whyte, K. A. Macdonald, L. Burton, R. T. Cursons, J. R. Roche, and C. W. Holmes. 2009. Somatotropic axis components and nutrient partitioning in genetically diverse dairy cows managed under different feed allowances in a pasture system. J. Dairy Sci. 92:526-539.

Lucy, M. C., W. J. Weber, L. H. Baumgard, B. S. Seguin, A. T. Koenigsfeld, L. B. Hansen, H. Chester-Jones, and B. A. Crooker. 1998. Reproductive endocrinology of lactating dairy cows selected for increased milk production. J. Anim. Sci. 76 (Suppl. 1):246. (Abstr.)

McCarthy, S. D., S. T. Butler, J. Patton, M. Daly, D. G. Morris, D. A. Kenny, and S. M. Waters. 2009. Differences in the expression of genes involved in the somatotropic axis in divergent strains of Holstein-Friesian dairy cows during early and mid lactation. J. Dairy Sci. 92:5229-5238.

Patton, J., D. A. Kenny, S. McNamara, J. F. Mee, F. P. O'Mara, M. G. Diskin, and J. J. Murphy. 2007. Relationships among milk production, energy balance, plasma analytes, and reproduction in Holstein-Friesian cows. J. Dairy Sci. 90:649-658.

Radcliff, R. P., B. L. McCormack, B. A. Crooker, and M. C. Lucy. 2003. Plasma hormones and expression of growth hormone receptor and insulin-like growth factor-I mRNA in hepatic tissue of periparturient dairy cows. J. Dairy Sci. 86:3920-3926.

Rajaram, S., D. J. Baylink, and S. Mohan. 1997. Insulin-like growth factor-binding proteins in serum and other biological fluids: Regulation and functions. Endocr. Rev. 18:801-831.

Ram, P. A., and D. J. Waxman. 1999. SOCS/CIS protein inhibition of growth hormone-stimulated STAT5 signaling by multiple mechanisms. J. Biol. Chem. 274:35553-35561.

Renaville, R., M. Hammadi, and D. Portetelle. 2002. Role of the somatotropic axis in the mammalian metabolism. Domest. Anim. Endocrinol. 23:351-360.

Rhoads, M. L., J. P. Meyer, W. R. Lamberson, D. H. Keisler, and M. C. Lucy. 2008. Uterine and hepatic gene expression in relation to days postpartum, estrus, and pregnancy in postpartum dairy cows. J. Dairy Sci. 91:140-150.

Rhoads, R. P., J. W. Kim, B. J. Leury, L. H. Baumgard, N. Segoale, S. J. Frank, D. E. Bauman, and Y. R. Bosclair. 2004. Insulin increases the abundance of the growth hormone receptor in liver and adipose tissue of periparturient dairy cows. J. Nutr. 134:1020-1027.

Rhoads, R. P., J. W. Kim, M. E. Van Amburgh, R. A. Ehrhardt, S J. Frank, and Y. R. Boisclair. 2007. Effect of nutrition on the GH responsiveness of liver and adipose tissue in dairy cows. J. Endocrinol. 195:49-58.

Sjögren, K., J.-L. Liu, K. Blad, S. Skrtic, O. Vidal, V. Wallenius, D. LeRoith, J. Törnell, O. G. P. Isaksson, J.-O. Jansson, and C. Ohlsson. 1999. Liver-derived insulin-like growth factor I (IGF-I) is the principal source of IGF-I in blood but is not required for postnatal body growth in mice. Proc. Natl. Acad. Sci. USA 96:7088-7092.

Smith, R. D., B. Brown, P. Ikonomi, and A. N. Schechter. 2003. Exogenous reference RNA for normalization of real-time quantitative PCR. Biotechniques 34:88-91.

Taylor, V. J., E. Kebreab, D. E. Beever, J. Mills, and D. C. Wathes. 2004. Physiological adaptations to milk production that affect the fertility of high yielding dairy cows. Pages $37-71$ in Br. Soc. Anim. Sci. Occ. Publ. No. 29. Nottingham University Press, Nottingham, UK.

Teglund, S., C. McKay, E. Schuetz, J. M. van Deursen, D. Stravopodis, D. Wang, M. Brown, S. Bodner, G. Grosveld, and J. N. Ihle. 1998. Stat5a and Stat5b proteins have essential and nonessential, or redundant, roles in cytokine responses. Cell 93:841-850.

Vandesompele, J., K. De Preter, F. Pattaun, B. Poppe, N. Van Roy, A. De Pape, and F. Speleman. 2002. Accurate normalization of real-time quantitative RT-PCR data by geometric averaging of multiple internal control genes. Genome Biol. 37:Research0034.

Veerkamp, R. F., B. Beerda, and T. van der Lende. 2003. Effects of genetic selection for milk yield on energy balance, levels of hormones, and metabolites in lactating cattle, and possible links to reduced fertility. Livest. Prod. Sci. 83:257-275.

Vicini, J. L., F. C. Buonomo, J. J. Veenhuizen, M. A. Miller, D. R. Clemmons, and R. J. Collier. 1991. Nutrient balance and stage of lactation affect responses of insulin, insulin-like growth factors I and II, and insulin-like growth factor-binding protein 2 to somatotropin administration in dairy cows. J. Nutr. 121:1656-1664.

Wathes, D. C., N. Bourne, Z. Cheng, G. E. Mann, V. J. Taylor, and M. P. Coffey. 2007. Multiple correlation analyses of metabolic and endocrine profiles with fertility in primiparous and multiparous cows. J. Dairy Sci. 90:1310-1325.

Wathes, D. C., V. J. Taylor, Z. Cheng, and G. E. Mann. 2003. Follicle growth, corpus luteum function and their effects on embryo development in postpartum dairy cows. Reprod. Suppl. 61:219-237.

Woelfle, J., and P. Rotwein. 2004. In vivo regulation of growth hormone-stimulated gene transcription by STAT5b. Am. J. Physiol. Endocrinol. Metab. 286:E393-E401. 